\title{
An Implementation of Repetitive Scheduling Method in Bus Transportation Schedule
}

\author{
Wistiani Astuti, Nia Kurniati, Dirgahayu Lantara
}

\begin{abstract}
Sustainable transportation is a transportation system that minimizes the impact on economic, social and environmental aspects. One of the land transportation used in Makassar is Bus Rapid Transit (BRT). Bus Rapid Transit (BRT) Trans Mamminasata is a public transportation service that can be used by the people of Makassar in middle and lower level. In public transport services is often found the uncertainty waiting time of bus arrival and departure at each stop. This research applies repetitive scheduling method in solving the scheduling problem to know the departure and arrival schedule of Bus Rapid Transit (BRT) at every stop. This research proposes the arrival and departure schedule of Bus Rapid Transit (BRT) based on each route at each stop. The result of the repetitive scheduling method is the duration of time and the number of units of the bus according to the condition intensity.
\end{abstract}

Keywords-Bus Rapid Transit (BRT); Repetitive Scheduling Method; Scheduling.

\section{INTRODUCTION}

Makassar is the largest city in eastern Indonesia. There are several transportations used include land, sea or air transportation. One of the existing road transportation in Makassar is Bus Rapid Transit (BRT) which is also called busway. One of the Makassar city government programs is to be a developing and smart city in facilitating all the needs by utilizing technology. The sustainable transportation system is a new order of transportation system in the current era of globalization [1]. Transportation is an issue that requires attention and study from various scientific perspectives [2]. Sustainable transportation is a transportation system that minimizes the impact on economic, social and environmental aspects. Bus Rapid Transit (BRT) Trans Mamminasata is a newly applied transportation service in Makassar. The transportation service is the important economic sector for the people of Makassar in middle and lower level due to the affordable cost, safeness and comfort. However, there are still many shortcomings found in the services.

One of the disadvantages found in BRT services is the uncertainty of waiting time of bus arrival and departure at each bus stop due to the scheduling which is still manual and not in real time yet. It causes the accumulation of passengers at the bus stop. Several passengers tend to be bored with this sort of conditions and change to another public transportation. Scheduling is an activity of allocating

Revised Manuscript Received on September 10, 2019.

Wistiani Astuti, Faculty of Computer Science, Universitas Muslim Indonesia, Makassar, Indonesia.

(E-mail: whistieruslank@gmail.com)

Nia Kurniati, Faculty of Computer Science, Universitas Muslim Indonesia, Makassar, Indonesia.

Dirgahayu Lantara, Faculty of Industrial Engineering, Universitas Muslim Indonesia. existing resources to run a set of tasks within a certain timeframe [3].

In order to solve the problem on the irregular and manual Bus Rapid Transit (BRT) schedule, it is necessary to conduct research on Bus Rapid Transit (BRT) scheduling by applying repetitive scheduling method to make and operate scheduling on Bus Rapid Transit (BRT) effectively.

\section{EXPERIMENTAL DETAILS}

Repetitive Scheduling Method (RSM) is a scheduling method that is generally used in projects with repetitive activities. In Critical Path Method, the main matter to note is that there is a critical path in the path that must be passed when doing scheduling in an activity sequence, whereas in repetitive scheduling method is the optimal material used [4], [5]. There are two important and often confused production rates associated with each activity, a resource production rate $\left(r p r_{A}\right)$ and a unit production rate $\left(u p r_{A}\right)$ [6]. The resource production rate for an activity, rprA is the amount of work that can be accomplished by the resource in one time period shown in equation (1).

$$
\operatorname{rpr}_{A}=\frac{Q_{A i}}{T_{A i}}
$$

As pointed in (1), rprA is the resource production rate; QAi is the quantity of work in activity, $\mathrm{A}$, in any repeating unit, $\mathrm{i}$; and TAi is the time needed to complete the A activity in unit i. (1) is most often used to estimate the activity duration, TAi, in as much as the quantity of work, QAi, is taken from the plans and specifications and a standardized resource production rate, $\mathrm{rprA}$, for the selected

resource and method is taken from company databases or from any of several construction guides in common use in the construction industry.

The unit production rate is the number of repetitive units that can be accomplished by a resource during a unit of time. For an activity, A, in any repeating unit, i, the unit production rate, uprAi, can be expressed as (2).

$$
\operatorname{upr}_{\mathrm{Ai}}=\frac{1}{T_{A i}} \text {. }
$$

It can be seen in (2) that TAi is the time needed to complete the unit. The unit production rate (and not the resource production rate) is the slope of a production line in an RSM diagram. If (1) is solved for TAi, substituted into (2), and applied to any repeating unit, we obtain (3).

$$
u p r_{A i}=\frac{r p r_{A}}{Q_{A i}}
$$

From the result of resource production rate and unit production rate of money obtained, so it can be calculated how good scheduling should be activity. The recurrent data 
in this paper is the updating of data on the Bus Rapid Transit (BRT) travel time of each stop in each corridor.

\section{RESULT AND DISCUSSION}

This research is more to design the simulation program for Repetitive Scheduling Method because to get the result of data that is close to reality is by doing updating data which is done continuously, follow the progress of the situation in reality [7]. At this stage, the application of the RSM method is determined into several variables such as: the number of activity stated as $r p r_{A}$, the number of repeating units expressed as $u p r_{A}$, the number of turns in a series of activities is expressed as $Q_{A i}$, and the time required in a single activity is stated as $T_{A i}$. The process for obtaining $r p r_{A}$ is obtained from $Q_{A i}$ divided by $T_{A i} . T_{A i}$ is divided by the speed divided by time, whereas to calculate the speed is obtained from the distance divided by the time. The time is obtained based on the real state of the data retrieval process. Meanwhile the distance to the unit per $\mathrm{km}$ is obtained from the distance from the departure point to the destination.

This research is performed to find the proper time planning. In achieving these objectives, we estimate the time completion of the activity. The data retrieval time is within seconds and the bus arrival time range is based on the result of observation and the testing which has been done that is 10-15 minutes. There are 11 corridors identified i.e. corridor 1 (Airport - Achmad Yani Street) round-trip, corridor 2 (Sudiang - Gowa) round-trip, corridor 3 (Boulevard Street Metro Tanjung Bunga Street) round-trip, corridor 4 (Daya Maros) round-trip, corridor 5 (UntiaStreet - Gowa) roundtrip, corridor 6 (Gowa - Metro Tanjung Bunga Street) round-trip, corridor 7 (Gowa - Takalar) round-trip, corridor 8 (Takalar - Metro Tanjung Bunga Street) round-trip, corridor 9 (Maros - Barombong) round-trip, corridor 10 (Tamalanrea Street - Gowa) round-trip. The data is based on each active corridor are corridor 1, 2, 3, and 4 .

Table 1: BRT departure schedule for corridor 2

\begin{tabular}{|c|c|c|c|c|c|c|}
\hline $\begin{array}{c}\text { Bus } \\
\text { Number }\end{array}$ & From & To & $\begin{array}{l}\text { Departu } \\
\text { re Time }\end{array}$ & $\begin{array}{l}\text { Arrival } \\
\text { Time }\end{array}$ & $\begin{array}{c}\text { rprA } \\
\text { (minute) }\end{array}$ & $\begin{array}{c}\text { uprA } \\
\text { (minu } \\
\text { te) }\end{array}$ \\
\hline B01 & UIN & LPMP & 08.05 & 08.05 & 28.6 & 4 \\
\hline B02 & LPMP & $\begin{array}{c}\text { Kampus } \\
\text { UMI }\end{array}$ & 08.10 & 08.25 & 19.0 & 2 \\
\hline B03 & $\begin{array}{c}\text { Kampus } \\
\text { UMI }\end{array}$ & $\begin{array}{c}\text { Kantor } \\
\text { Gubernur }\end{array}$ & 08.30 & 08.34 & 32.0 & 4 \\
\hline B04 & $\begin{array}{c}\text { Kantor } \\
\text { Gubernu } \\
\mathrm{r}\end{array}$ & $\begin{array}{l}\text { UIM Al- } \\
\text { Ghazali }\end{array}$ & 08.39 & 08.47 & 20.6 & 3 \\
\hline B05 & $\begin{array}{l}\text { UIM Al- } \\
\text { Ghazali }\end{array}$ & $\begin{array}{c}\text { Dinas } \\
\text { Pendidika } \\
\mathrm{n}\end{array}$ & 08.52 & 08.54 & 22.9 & 3 \\
\hline B06 & $\begin{array}{c}\text { Dinas } \\
\text { Pendidik } \\
\text { an }\end{array}$ & $\begin{array}{c}\text { BRT } \\
\text { UNHAS }\end{array}$ & 08.59 & 09.01 & 24.6 & 3 \\
\hline B07 & $\begin{array}{c}\text { BRT } \\
\text { UNHAS }\end{array}$ & Daya & 09.06 & 09.17 & 20.4 & 3 \\
\hline B08 & Daya & $\begin{array}{c}\text { Dinas } \\
\text { Perhubung } \\
\text { an }\end{array}$ & 09.22 & 09.24 & 26.7 & 3 \\
\hline B09 & $\begin{array}{c}\text { Dinas } \\
\text { Perhubu } \\
\text { ngan }\end{array}$ & $\begin{array}{l}\text { Kementeri } \\
\text { an } \\
\text { Lingkunga } \\
\text { n Hidup }\end{array}$ & 09.29 & 09.35 & 24.3 & 3 \\
\hline B10 & $\begin{array}{c}\text { Kemente } \\
\text { rian } \\
\text { Lingkun }\end{array}$ & $\begin{array}{l}\text { Citra } \\
\text { Sudiang } \\
\text { Indah }\end{array}$ & 09.40 & 09.42 & 28.2 & 4 \\
\hline B11 & $\begin{array}{l}\text { gan } \\
\text { Hidup } \\
\text { Citra } \\
\text { Sudiang } \\
\text { Indah } \\
\end{array}$ & $\begin{array}{c}\text { Buni } \\
\text { Permata } \\
\text { Sudiang }\end{array}$ & 09.47 & 09.49 & 32.0 & 4 \\
\hline
\end{tabular}

Table 1 shows that the highest average activity sequence obtained from the number of activity performed at one time is 4 routes. The first is the departure route point from "UIN Stop" to "LPMP Stop", rprA of 28.6 and uprA of 4 repeating units. Secondly, the route from "UMI Campus" to "Office of Governor" with rprA achievement of 32.0 and uprA of 4 repeating units. The third, the route from "Ministry of Environment Stop" to "Citra Sudiang Indah Stop" with rprA of 28.2 and uprA of 4 repeating units. The fourth is the route from "Citra Sudiang Indah Stop" to "Sudiang Gem Stop" with rprA a of 32.0 and uprA of 4 repeating units. The four routes are the most frequent in involving the resources in each activity sequence. In Table 2, the BRT return schedule is obtained for corridor 2 .

Table 2 shows that the highest average activity sequence obtained from the number of activities performed at one time is 5 routes. The first is the departure route from "Citra Sudiang Indah Stop" to the "Ministry of Environment" Stop, with rprA of 35.6 and uprA of 4 repeating units. Secondly, the return route from "Transportation Department Stop" to "Power Stop" with rprA of 30.8 and uprA of 4 repeating units. The third, the return route from "Power Stop" to "Tamalanrea Stick Stop" with rprA of 28.2 and uprA of 4 repeating units. The fourth, the return route from the "Office of Governor" to "Univ.Bosowa" Stop with rprA of 33.7 and uprA of 4 repeating units. The fifth, the return route from "Halte Panakukkang" to "Campus Stop UNM" with rprA of 30.8 and uprA as many as 4 units are repeated. The five routes are the most frequent in involving a lot of resources in each activity sequence.

Table 2: BRT return schedule for corridor 2

\begin{tabular}{|c|c|c|c|c|c|c|}
\hline $\begin{array}{l}\text { Bus } \\
\text { Num } \\
\text { ber }\end{array}$ & From & To & $\begin{array}{l}\text { Depart } \\
\text { ure } \\
\text { Time }\end{array}$ & $\begin{array}{c}\text { Arri } \\
\text { val } \\
\text { Tim } \\
\text { e }\end{array}$ & $\begin{array}{l}\text { rprA } \\
\text { (min } \\
\text { ute) }\end{array}$ & $\begin{array}{l}\text { uprA } \\
\text { (min } \\
\text { ute) }\end{array}$ \\
\hline B01 & $\begin{array}{c}\text { Bumi } \\
\text { Permata } \\
\text { Sudiang }\end{array}$ & $\begin{array}{c}\text { Citra } \\
\text { Sudiang } \\
\text { Indah }\end{array}$ & 09.49 & $\begin{array}{c}10.0 \\
9\end{array}$ & 26.7 & 3 \\
\hline B02 & $\begin{array}{l}\text { Citra } \\
\text { Sudiang } \\
\text { Indah }\end{array}$ & $\begin{array}{l}\text { Kementeri } \\
\text { an } \\
\text { Lingkunga } \\
\text { n HIdup }\end{array}$ & 10.14 & $\begin{array}{c}10.1 \\
7\end{array}$ & 35.6 & 4 \\
\hline B03 & $\begin{array}{l}\text { Kementeri } \\
\text { an } \\
\text { Lingkunga } \\
\text { n HIdup }\end{array}$ & $\begin{array}{c}\text { Dinas } \\
\text { Perhubung } \\
\text { an }\end{array}$ & 10.22 & $\begin{array}{c}10.2 \\
6\end{array}$ & 17.4 & 2 \\
\hline B04 & $\begin{array}{c}\text { Dinas } \\
\text { Perhubung } \\
\text { an }\end{array}$ & Daya & 10.31 & $\begin{array}{c}10.3 \\
3\end{array}$ & 30.8 & 4 \\
\hline B05 & Daya & $\begin{array}{c}\text { Stik } \\
\text { Tamalanre } \\
\text { a }\end{array}$ & 10.38 & $\begin{array}{c}10.4 \\
8\end{array}$ & 28.2 & 4 \\
\hline B06 & $\begin{array}{c}\text { Stik } \\
\text { Tamalanre } \\
\text { a }\end{array}$ & $\begin{array}{c}\text { Univ. } \\
\text { Cokroamin } \\
\text { oto }\end{array}$ & 10.53 & $\begin{array}{c}10.5 \\
6\end{array}$ & 21.8 & 3 \\
\hline B07 & $\begin{array}{c}\text { Univ. } \\
\text { Cokroamin } \\
\text { oto }\end{array}$ & $\begin{array}{c}\text { Dinas } \\
\text { Pendidikan }\end{array}$ & 11.01 & $\begin{array}{c}11.0 \\
3\end{array}$ & 23.5 & 3 \\
\hline B08 & $\begin{array}{c}\text { Dinas } \\
\text { Pendidikan }\end{array}$ & $\begin{array}{c}\text { KantorGub } \\
\text { ernur }\end{array}$ & 11.08 & $\begin{array}{c}11.2 \\
3\end{array}$ & 20.0 & 3 \\
\hline B09 & $\begin{array}{c}\text { KantorGub } \\
\text { ernur }\end{array}$ & $\begin{array}{l}\text { Univ. } \\
\text { Bosowa }\end{array}$ & 11.23 & $\begin{array}{c}11.2 \\
7\end{array}$ & 33.7 & 4 \\
\hline B10 & $\begin{array}{l}\text { Univ. } \\
\text { Bosowa }\end{array}$ & $\begin{array}{c}\text { Mall } \\
\text { Panakkuka } \\
\text { ng }\end{array}$ & 11.32 & $\begin{array}{c}11.4 \\
3\end{array}$ & 23.8 & 3 \\
\hline
\end{tabular}




\begin{tabular}{|c|c|c|c|c|c|c|}
\hline B11 & $\begin{array}{c}\text { Mall } \\
\text { Panakkuka } \\
\text { ng }\end{array}$ & $\begin{array}{c}\text { Kampus } \\
\text { UNM }\end{array}$ & 11.48 & $\begin{array}{c}11.5 \\
8\end{array}$ & 30.8 & 4 \\
\hline B12 & $\begin{array}{c}\text { Kampus } \\
\text { UNM }\end{array}$ & $\begin{array}{l}\text { Kampus } \\
\text { Unismuh }\end{array}$ & 12.03 & $\begin{array}{c}12.0 \\
9\end{array}$ & 22.9 & 3 \\
\hline B13 & $\begin{array}{l}\text { Kampus } \\
\text { Unismuh }\end{array}$ & $\begin{array}{c}\text { Jl. Raya } \\
\text { Gowa }\end{array}$ & 12.14 & $\begin{array}{c}12.3 \\
3\end{array}$ & 23.8 & 3 \\
\hline B14 & $\begin{array}{c}\text { Jl. Raya } \\
\text { Gowa }\end{array}$ & $\begin{array}{l}\text { Terminal } \\
\text { Pallangga }\end{array}$ & 12.38 & $\begin{array}{c}12.4 \\
2\end{array}$ & 20.0 & 3 \\
\hline
\end{tabular}

\section{CONCLUSION}

Based on Table 1 and Table 2 on corridor 2, data of departure schedule and arrival schedule of each route are obtained. The data obtained represents the reality. The highest activity of the number of activities performed in one time can provide information about the most frequent route to pass, and some units are repeated from the departure and arrival schedule for each route on each BRT Trans bus corridor.

\section{ACKNOWLEDGEMENT}

The authors would like to express heartfelt thanks to PERUM DAMRI in Makassar City which has given us the opportunity to do research. We also appreciate the Institute for Research and Development of Resources UMI (LP2S UMI) with under Contract 0334/A.03/LP2S-UMI/IV/2016) for providing financial support.

\section{REFERENCES}

1. M. M. Anad, M. A. Subhi, and M. A. Mohammed, "SelfSustainable Intelligent Transportation System," Int. J. Eng. Technol., vol. 7, no. 3.20, pp. 759-763, 2018.

2. L. Schipper, "Sustainable urban transport in the $21 \mathrm{st}$ century: a new agenda," Transp. Res. Rec., vol. 1792, no. 1, pp. 12-19, 2002.

3. K. R. Baker, Introduction to sequencing and scheduling. John Wiley \& Sons, 1974.

4. K. G. Mattila and A. Park, "Comparison of linear scheduling model and repetitive scheduling method," $J$. Constr. Eng. Manag., vol. 129, no. 1, pp. 56-64, 2004.

5. S. Surahman, A. Viddy, A. F. O. Gaffar, H. Haviluddin, and A. S. Ahmar, "Selection of the best supply chain strategy using fuzzy based decision model," Int. J. Eng. Technol., vol. 7, no. 2.2, pp. 117-121, 2018.

6. R. B. Harris and P. G. Ioannou, "Repetitive scheduling method." Michigan, 1998.

7. R. Y. Huang and D. W. Halpin, "Graphically based LP modelling for linear scheduling analysis: the POLO system," Eng. Constr. Archit. Manag., vol. 7, no. 1, pp. 41-51, 2000. 